\title{
Applications of Right Speech in Knowledge Management and Organizational Learning
}

Kalpana Mishra $(\mathrm{PhD})$

\begin{abstract}
The focus of this research is more on the applications of Right Speech (RS) in Knowledge Management (KM) and Organizational Learning (OL) in the context of Nepal. The primary motivation of the researcher is to see whether people at the managerial level do use right speech in relation to KM and OL. We would agree the fact that the job of quantifying values into numeric system is not an easy one; therefore, mixed-method has been carried out as a tool so as to interpret the quantitative, qualitative, and the content of Key Informant Interviews (KIIs). The mixed-method is the integration of qualitative and quantitative approaches or methods in a single study or program of inquiry, and this is what the researcher has done here in the Nepalese organizations that deal with various sectors such as education, finance, human resource development, profit and non-profit etc.
\end{abstract}

Keywords: Right Speech, Knowledge Management, Organizational Learning

\section{Introduction}

The researcher, in this study, has studied the applications of Right Speech (RS) on Knowledge Management (KM) and 
Organizational Learning (OL) in Nepalese organizations. It was, particularly, based on mixed-method. Mixed-method is defined as 'the class of research where the researcher mixes or combines quantitative and qualitative research techniques, methods, approaches, concepts or language into a single study' (Johnson \& Onwuegbuzie, 2004). Quantitative information was collected with 220 respondents from different Nepalese organizations. The qualitative sample consists of 10 participants using triangulation method. All participants involved in Key Informant Interviews (KIIs) were managerial level staffs, with the knowledge on Buddhism, who were in the capacity to influence their subordinates. A purposeful sampling strategy was used. An interview was conducted with 10 participants who were already included for the quantitative study.

According to Hanh (1999), the Noble Eightfold Path (NEP) is practiced to achieve joy, peace, and insight in the mind. The eightfold practice contains the gist of many thousand discourses scattered in Buddhist scriptures (Bodhi, 1994). Right speech is one component among eight components of NEP. The application of right speech in the domains of KM and OL has been one of the interesting topics of study in the context of Nepal. There are several moments and situations in which people working for the different organizations tend to follow the elements embedded in the NEP, but those who do it realizing its value, and for the good of the organization and that of its staff members, would achieve better results in terms of productivity, excellence, and quality. The fact of knowledge, whether ancient or modern, is a matter of constant sharing and management with flexibility in understanding and complete mindfulness. An organization is expected to grow 
up along with the discipline formed in its atmosphere that is more conducive to exchange ideas and experiences amongst its staff members and also with the one at the managerial level. The right speech, despite being simple in its theme, has now been considered to be scientific and practicable to the people of many organizations. But to those taking up the responsibility of managing things in an organization, the RS enhances KM practices and does strengthen OL (Mishra, 2018).

Most of the managers involved in the research task mentioned that they directly or indirectly applied the RS in their organizations. A manager with awareness in Buddhist values and disciplines can better practice them in the respective organization which would eventually be an opportunity for others to learn and grow up psychologically.

\section{The Right Speech}

The classical explanation of Right Speech is: i. Speaking truthfully: When something is green, we say it is green, and not purple; ii. Not speaking with a forked tongue; iii. Not speaking cruelly. We don't shout, slander, curse, encourage suffering, or create hatred. Even those who have a good heart and don't want to hurt others sometimes allow toxic words to escape from their lips; iv. Not exaggerating or embellishing (Jack, 1995).

Saying what one means and meaning what one says is only part of right speech. Avoiding harmful or divisive speech is also essential to those who admire Buddhist values (Rahula, 
1974). Employing right speech does not justify sharing information about others even if the information is true. If the words hurt someone's feelings, revealing the information to others should not occur. Thoughtful leaders will address any professional shortcomings to the employee directly, not to the employee's peers. Sarcasm is another trait to be avoided under right speech. While the person who makes sarcastic remarks might think him or herself very clever, the cleverness is often at the expense of someone else.

Another part of right speech is to rejoice in the virtues and good qualities of others, while avoiding idle chatter (Ibid). Engaging in wholesome conversation earns leaders a good reputation. No one respects people who spread stories about others. Eventually, the stories will take a very negative tone that reflects badly on the carrier. Many people have lost jobs and careers because they confided in the wrong person.

\section{Knowledge Management (KM)}

There is no universally accepted definition of KM. But there are numerous definitions proffered by experts. Put very simply, knowledge management is the conversion of tacit knowledge into explicit knowledge and sharing it within the organization. Putting it more technically and accurately, KM is the process through which organizations generate value from their intellectual and knowledge based assets.

According to Filemon and Uriarte (2008), a complete knowledge management system must contain four elements. These are: (a) knowledge creation and capture, (b) knowledge sharing and enrichment, (c) information storage and retrieval, 
and (d) knowledge dissemination. The processes of $\mathrm{KM}$ involve knowledge creation, acquisition, refinement, storage, transfer, sharing, and utilization. The KM function in the organization operates these processes, develops methodologies and systems to support them, and motivates people to participate in them. The goals of KM are the leveraging and improvement of the organization's knowledge assets to effectuate better knowledge practices, improved organizational behaviors, better decisions and improved organizational performance (Alexopoulos, 2008).

According to Filius et al. (2000), knowledge management consists knowledge creation, acquisition, application, storage, and dissemination.

\section{Organizational Learning (OL)}

Generally organizational challenges call for learning and creativity, there is no consensus around what organizational learning is or how to best facilitate it. Kim (2003) defines OL is simply the sum of what individuals in organizations learn, Levitt, \& March (1998) contend that OL is a reflection of the collective ideas, activities, processes, systems, and structures of the organization.

Thomsen and Hoest (2001) see that the learning and OL as two sides of the same coin considering that the OL is the central activity in the learning. However, it is very important to understand the meaning of OL. Garvin (1993) definition of $\mathrm{OL}$ relies on the requirements that an organization must satisfy in order to become a learning organization. He defines the learning organization as an organization that is skilled at 
creating, acquiring, and transferring knowledge, and at modifying its behavior to reflect new knowledge and insights.

Although researchers have defined organizational learning in different ways, Easterby-Smith and Lyles (2003) definitions is that organizational learning is a change in the organization that occurs as the organization acquires experience. The question then becomes changes in what. Although researchers have debated whether organizational learning should be defined as a change in cognitions or behavior, that debate has waned (Easterby-Smith \& Lyles, 2003). Most researchers would agree with defining organizational learning as a change in the organization's knowledge that occurs as a function of experience (Fiol and Lyles 1985). This knowledge can manifest itself in changes in cognitions or behavior and include both explicit and tacit or difficult-to-articulate components. The knowledge could be embedded in a variety of repositories, including individuals, routines and transactive memory systems. Although we use the term knowledge, our intent is to include both knowledge in the sense of a stock and knowing in the sense of a process (Cook \& Brown, 1999).

\section{Objectives}

Overall objective of this study was to make an investigation of the applications of RS in KM and OL in the context of Nepalese organizations using mixed methods. 


\section{Research Questions}

Following are the research questions of this study:

i. Is Right Speech (RS) applicable in Knowledge Management (KM)?

ii. Is Right Speech (RS) applicable in Organizational Learning (OL)?

iii. Do managers believe that they can use RS in (KM) and $(\mathrm{OL})$ ?

iv. Do managers have a role in supporting the applications of RS in their organizations?

First and second questions have been specifically answered by the quantitative study. Data has been collected from the structured set of questionnaire. Descriptive, correlation, and regression analysis have been applied to test the proposed assumptions.

Qualitative component of this study is to answer the third and fourth research questions. Qualitative data has been collected through Key Informant Interviews (KIIs) and Open-Ended Question (OEQ) methods.

\section{Methods and Samples}

The population of interest, in this research study, included managerial level employees of various organizations 
representing the decision making capability regarding the organizational work.

Hence, the target population included minimum officer level staffs, with the working experience of more than a year, from the organizations having a minimum of ten staff members. An extensive search for potential participant organizations was first conducted by informal talk with employees of the respective or selected organizations. The aim was to gather information about whether they can meet the required criteria to participate in research work or not. An initial pool of organizations fitting the criteria for the target population was selected.

The researcher worked on the quantitative data initially, but for the qualitative section, the researcher mainly put priority on the individual participants with some knowledge and experience on Buddhism. For the purpose of quantitative part 220 employees of different organizations were included. For the purpose of qualitative sample, ten respondents were included as KIIs.

\section{Results and Discussion}

The purpose behind using mixed-method is to identify the applications of RS in the Nepalese organizations, based on the quantitative and qualitative findings, in relation to $\mathrm{KM}$ and OL. Since the Buddhist teachings are more about the psychological aspects, it is almost hard to completely depend on the quantitative findings for the end results. It is for this reason that the researcher applied the mixed-method, 
considering this to be the best one. The mixing of qualitative and quantitative data has offered a better sense for the research outcome.

According to Creswell (2014) mixed methods research requires integration or mixing of quantitative and qualitative data at some point during the research process. Researchers should clearly explain and depict in a visual model where data integration is to occur. In addition, researchers should clarify whether it is methods, data, or findings that are being combined (Punch, 1998).

Table 1 was developed to illustrate findings from the quantitative and qualitative sections of the research. These findings were related to the findings obtained from the questionnaire survey.

\section{Descriptive Statistics of Right Speech}

Table 1: Matrix on Qualitative and Descriptive Response Status

\begin{tabular}{|l|l|l|l|}
\hline Questions & Mean & SD & Response \\
\hline RS & 5.98 & 0.720 & $\begin{array}{l}\bullet \text { RS is core of the } \\
\text { Buddhist teachings, specially } \\
\text { one component of NEP; it is } \\
\text { useful because they are based on } \\
\text { the Nepalese/eastern culture. } \\
\text { They should be brought into } \\
\text { practice in day to day living of }\end{array}$ \\
\hline
\end{tabular}




\begin{tabular}{|c|c|c|c|}
\hline & & & $\begin{array}{l}\text { an individual. Staff members } \\
\text { have the chance to be more } \\
\text { decent by following NEP. } \\
\text { - The NEP including RS is } \\
\text { partially applied in my } \\
\text { organization and it has still to } \\
\text { walk a long way ahead. } \\
\text { - RS is an effective tool to } \\
\text { apply in an organization because } \\
\text { it helps make a person less } \\
\text { violent while practicing his/her } \\
\text { power and authority. }\end{array}$ \\
\hline $\mathrm{KM}$ & 5.18 & 0.94 & $\begin{array}{l}\text { - Intensive and frequent } \\
\text { meetings, discussions, sharing, } \\
\text { exchange of ideas, receiving } \\
\text { feedback, comments, timely } \\
\text { corrections, involvement of all } \\
\text { stakeholders are practiced in my } \\
\text { organization. We have the } \\
\text { culture of getting things done in } \\
\text { a team. } \\
\text { - Indeed, } \\
\text { implementing various strategies } \\
\text { for KM like staff meetings, } \\
\text { group counseling for staffs and } \\
\text { documentation of the activities }\end{array}$ \\
\hline
\end{tabular}




\begin{tabular}{|c|c|c|c|}
\hline & & & $\begin{array}{l}\text { accomplished, planned or } \\
\text { scheduled. } \\
\text { - One of the best things I } \\
\text { always appreciate of my } \\
\text { organization is that everyone } \\
\text { here sit together and share their } \\
\text { individual experiences which is } \\
\text { an opportunity for everyone to } \\
\text { get acquainted with something } \\
\text { new and different kind of } \\
\text { learning. }\end{array}$ \\
\hline $\mathrm{OL}$ & 5.04 & 1.06 & $\begin{array}{l}\text { - Organizational learning } \\
\text { occurs through team work, } \\
\text { brainstorms, and trustworthiness } \\
\text { among the human resources at } \\
\text { all levels. } \\
\text { - } \text { I strongly categorize my } \\
\text { institution as a learning } \\
\text { organization because employees } \\
\text { get ample space for learning by } \\
\text { means of tea-talk, workshop, } \\
\text { meetings, seminars etc } \\
\text { - I don't get confused to } \\
\text { rate my institution as a learning } \\
\text { organization where all the staff } \\
\text { members sit together in order to } \\
\text { discuss and share important } \\
\text { issues and challenges in order to }\end{array}$ \\
\hline
\end{tabular}




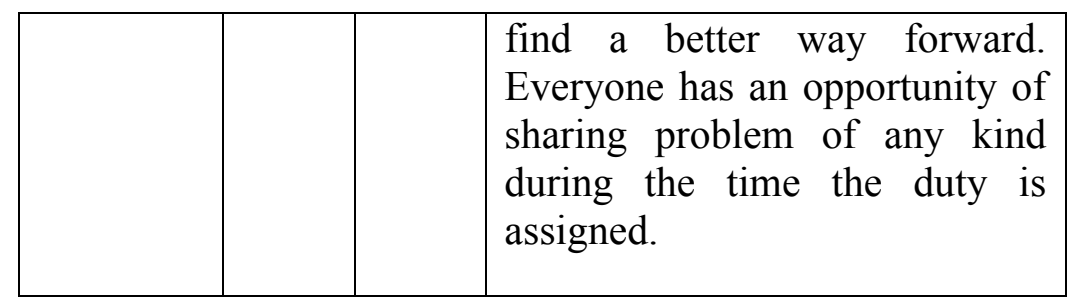

Source: Mishra, K. (2018)

Table 2 presents the findings from correlation and regression between study variables and comments from the Key Informant Interviews (KIIs) that correspond to those questions. The quantitative result is sufficiently supported by the qualitative responses received through KIIs.

\section{Table 2: Qualitative and Quantitative Response Status}

\begin{tabular}{|c|c|c|}
\hline & $\begin{array}{l}\text { Correlation and } \\
\text { regression with RS }\end{array}$ & Response \\
\hline KM & $\begin{array}{l}r=0.296 \\
\beta=.387, p<.000\end{array}$ & $\begin{array}{l}\text { - RS helps to manage } \\
\text { knowledge and also } \\
\text { encourages for learning } \\
\text { opportunity in the } \\
\text { organizations. } \\
\text { - The RS, when applied by } \\
\text { managerial level employees, } \\
\text { is really helpful in KM and } \\
\text { OL, but the leaders need to }\end{array}$ \\
\hline
\end{tabular}




\begin{tabular}{|c|c|c|}
\hline & & $\begin{array}{l}\text { act as a role model, for the } \\
\text { others to follow them. } \\
\text { - RS is useful everywhere and } \\
\text { for everybody, for instance, } \\
\text { if people fail practice right } \\
\text { speech the organization } \\
\text { eventually tends to shrink. }\end{array}$ \\
\hline OL & $\begin{array}{l}r=0.236 \\
\beta=.345, p<.001\end{array}$ & $\begin{array}{l}\text { - The RS properly guides not } \\
\text { only in KM and OL, but also } \\
\text { to be a true human being. } \\
\text { - When we help people } \\
\text { cultivate values and } \\
\text { morality, they might learn } \\
\text { more quickly and } \\
\text { effectively. } \\
\text { - Although, KM and OL have } \\
\text { not been maturely } \\
\text { established on the } \\
\text { background of NEP, it is } \\
\text { deemed an important } \\
\text { driving force to achieve a } \\
\text { success in the present day } \\
\text { globalization. } \\
\text { Learning raperes } \\
\text { cooperation among the staff } \\
\text { members and it grows along }\end{array}$ \\
\hline
\end{tabular}


\begin{tabular}{|l|l|l|}
\hline & $\begin{array}{l}\text { with the use of RS which is } \\
\text { why I am happy. }\end{array}$ \\
\hline
\end{tabular}

Source: Mishra, K. (2018)

Significant at 0.000 level (2 tailed).

\section{Conclusion}

$\mathrm{KM}$ and OL have been covered in the existing literature, but to date, no research has been linked with NEP and its components for the enhancement of KM and OL, and the interactions between these concepts have been taken for granted. As of now, good deal of researches has been conducted on the externals aspects relating with $\mathrm{KM}$ and OL, but not the internal and psychological ones; for example, right views, right thinking, right speech, right action, right livelihood, right effort, right mindfulness and right concentration. Considering this to be a central concern, the researcher has tried to find out the applications of RS in the domains of KM and OL in Nepalese organizations, and also the attitudes and beliefs of employees at managerial level, for the applications of such teachings in their institutions.

RS is not only for monks and nuns, but also for the people working in different organizations working for the good of the society. Right speech leads towards positive inquiry, positive action, positive learning, love, peace, and eventually brings change in the organizations as well as employees working in the organizations. Moreover, all these positive actions that replaces the hatred, disharmony and the tendency to harm 
others, and will facilitate for the enhancement and applications of KM and OL in the organization.

Literature reviews as well as the research findings show that RS has significant contribution in each and every walk of life including several different organizations. Specially, managerial level employees, being responsible for the organizational activities, can support their subordinates to follow the NEP and its components in their organizations.

On summing up the responses provided by the research participants it was learned that almost all the managers agreed the fact that RS is crucial factor to lead the organizations to the right directions as they have the power to influence, use creativity, provide decisions etc.

Furthermore, from the discussions in previous section, following conclusions are drawn on:

- Right Speech refers to abstaining from harsh speech, slander, lying, and idle speech or gossip. It has a mean value of 5.98 that means, respondents do "agree" with this variable.

- The 7-point Likert scale was used with the respondents indicate the extent to which they agreed or disagreed with the statements they were presented. KM practices have a composite mean of 5.18 .

- OL practices in Nepalese organizations generally show an average level of status. OL have mean values 5.04. It indicates that there are OL practices, but needs to be enhanced more. 
- The correlation results between RS and $\mathrm{KM}$ is ( $\mathrm{r}=$ $\left.0.296^{* *}\right)$; Such a result of correlation analysis is confirmed by the regression analysis conducted which showed RS ( $\beta=0.387, \mathrm{P}<0.000)$, implying 38.7 percent of the change in KM might be accounted by RS.

- RS showed low but positive significant correlation with OL. Finding of correlation is $\left(\mathrm{r}=0.236^{* *}\right)$; the simple regression analysis results was significant for $\mathrm{RS}(\beta=$ $0.345, \mathrm{P}<0.001)$. Implying 34.5 percent of the change in OL might be accounted by RS.

- The implication of such a finding is that the institutions which have applied RS are more likely to experience improved KM and OL. This finding supports the proposition that RS has a significant influence on KM and OL. It is supported by the results of the Key Informant Interviews (KIIs) also.

\section{References}

Alexopoulos, A. (2008). Social relations, human resource management, and knowledge transfer in work organizations: Toward an integrated approach.

Dissertation, Dublin City University, Business School.

Bodhi, B. (1994). Transcendental dependent arising. Sri Lanka: Buddhist Publication Society.

Cook, S., \& Brown, J.S. (1999). Bridging epistemologies: The generative dance between organizational knowledge and organizational knowing. Organization Science, 10(4), $381-400$. 
Creswell, J. W. (2014). Research design: Qualitative, quantitative, and mixed methods approaches (4th ed.). Thousand Oaks, CA: Sage.

Easterby-Smith, M., \& Lyles, M. (2003). Introduction: Watersheds of organizational learning and knowledge management. Oxford: Blackwell Publishing.

Filemon A., \& Uriarte, J.R. (2008). Introduction to knowledge management. Asian Foundation, Jakarta, Indonessia.

Filius, R., De Jong, J. \& Roefs, C. E. (2000). Knowledge management in the HRD office: A comparison of three cases, Journal of Workplace Learning, 12(7), pp. 286295.

Fiol, C. M., \& Lyles, M. A. (1985). Organizational learning. Academy of Management Review, 10(4).

Garvin, D. (1993). Building a learning organization. Harvard Business Review, 7(4), 78-91.

Hanh, T.H. (1999). The heart of the Buddha's teaching, last accessed 20 September, 2015, from www.randomhouse.co.uk.

Johnson, R.B. \& Onwuegbuzie, A.J. (2004). Mixed methods research: a research paradigm whose time has come. Educational Researcher, 33 (7), pp. 14-26.

Kim, S. (2003). Research paradigms in organizational learning and performance: Competing modes of inquiry. Information Technology, Learning, and Performance Journal, 21(1), 9-18.

Kornfield, J. (1995). The Eightfold Path for the householder. Dharma Net International. www.buddhanet.net.

Levitt, B., \& March, J. G. (1988). Organizational learning. Annual Review of Sociology, 14, 319-340. 
Mishra, K. (2018). An analytical study of the applications of Noble Eightfold Path in knowledge management and organizational learning. PhD Dissertation submitted to Lumbini Buddhist University (LBU). Nepal.

Punch, K. F. (1998). Introduction to social research: Quantitative and qualitative approaches. London: Sage Publications. (Chapter 11: Mixed Methods and Evaluative Criteria)

Rahula, W. (1974). What the Buddha taught. New York, NY: Grove Weidenfeld.

Thomsen, H. K., \& Hoest, V. (2001). Employees' perception of the learning organization. Management Learning, 32(4): 469-491.

Author's email: kmishra222@gmail.com 